\title{
Star-shaped conjugated oligoelectrolyte for bioimaging in living cells
}

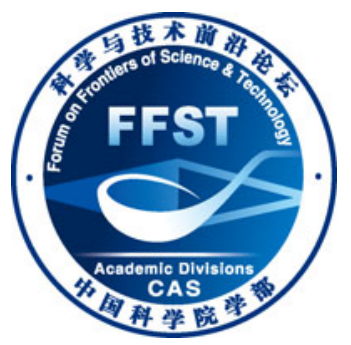

\author{
SONG WenLi, JIANG RongCui, YUAN Yan, LU XiaoMei, HU WenBo, \\ FAN QuLi* \& HUANG Wei*
}

Key Laboratory for Organic Electronics \& Information Displays (KLOEID) and Institute of Advanced Materials (IAM), Nanjing University of Posts \& Telecommunications (NJUPT), Nanjing 210046, China

Received September 6, 2012; accepted January 29, 2013; published online May 3, 2013

\begin{abstract}
A new star-shaped oligoelectrolyte (TEFCOONa) with triphenylamine as the core, acetylene as linkage and anionic fluorenes as arms was obtained and used for direct imaging in living PANC-1 cells. Because of the hydrophobic conjugated groups of the oligoelectrolyte, TEFCOONa can form nanospheres with an average diameter of $\sim 75 \mathrm{~nm}$ in $10 \mathrm{mmol} / \mathrm{L}$ PBS. These nanospheres possess a relatively high absolute quantum yield (16.5\% in PBS), low cytotoxicity and can penetrate into the nucleus through the cytoplasm, which is essential for living cellular imaging. Collectively, these results validate our rational design of conjugated oligoelectrolyte and even hyper branched polymers-copolyelectrolyte as effective nanovectors for bioimaging and other clinical applications.
\end{abstract}

star-shaped, oligoelectrolyte, absolute quantum yield, nanospheres, bioimaging

Citation: $\quad$ Song W L, Jiang R C, Yuan Y, et al. Star-shaped conjugated oligoelectrolyte for bioimaging in living cells. Chin Sci Bull, 2013, 58: 2570-2575, doi: $10.1007 / \mathrm{s} 11434-013-5796-0$

Over the past decades, conjugated polyelectrolytes (CPEs) have been widely used in sensing and cell imaging due to their intriguing optoelectronic and biocompatible properties [1-6]. Structurally, conjugated polyelectrolytes (CPEs) are fluorescent macromolecules with electron-delocalized backbone and water-soluble side chains which determine the main optical properties and capability to dissolve in water for their further biological applications respectively. So far, plenty of CPEs have been obtained through palladium-catalyzed coupling reactions (Suzuki, Heck, Snogashira), such as polyfluorene (PF), poly( $p$-phenyleneethynylene) (PPE), polydiacetylene (PDA), poly(thiophene) (PT) [7-9] and so on. These materials owning relatively high photoluminescent (PL) quantum yield (QY) and good water-solubility as depicted have formed an excellent basis for chemical and biological sensors. But their applications in cell imaging are seldom reported, possibly because the linear geometries

*Corresponding authors (email: wei-huang@njupt.edu.cn; iamqlfan@njupt.edu.cn) affect the cellular uptake process [10]. Therefore it is necessary to exploit CPEs with suitable geometries for cell imaging.

On that basis, hyperbranched conjugated macromolecules with three-dimensional (3-D) architectures and watersoluble groups were designed and synthesized for a variety of applications especially for cell imaging. Their threedimensional architectures usually contain three parts: photosynthetic centers giving them advantages for light harvesting, one or more branches improving the $\pi$-electron delocalization [11,12], and terminal groups [13]. All of these realize the electron and energy effective transfer through the whole molecular, which is facilitated to light harvesting.

Besides, we can regulate their size by changing groups. Unfortunately, so far water-soluble hyperbranched conjugated polymers are rarely developed, although their organicsoluble counterparts such as three or six-armed polymers $[14,15]$ and so on, have been explored for use in organic 
electronics in many literatures [16]. Notably, Wang et al. [12] and Li et al. [17] have synthesized a series of water-soluble hyperbranched polymers such as star-shaped glycosylated conjugated, hyperbranched conjugated polyelectrolyte and so on for cell imaging recently. Generally, the frames of their polyelectrolytes containing triphenylamine, fluorene, benzene and other groups, were linked by Suzuki reaction or Oralkyne polycyclotrimerization. Figure 1 shows their chemical structures clearly. These materials form different sizes of nanospheres in buffer solution easily. Advantages of the nanospheres: facilitating cellular uptake; low cytotoxicity and possessing high quantum yield, indicate that these polymers are ideal candidates for biological applications. But considering varied clinical applications, it is necessary to exploit a new type of hyperbranched conjugated polymers.

In this contribution, we designed and synthesized a new 3-D star-shaped oligoelectrolyte (TEFCOONa) through the sonogashira reaction firstly. The molecular was designed based on a triphenylamine core and anionic fluorenes, which ensure its strong fluorescence and good water solubility. Dissolved into the buffer solution, the oligoelectrolyte self-assemble to nanospheres and that is good for cytophagy. Then we use RAW 264.7 cells to study the cytophagy. PANC-1 (Human pancreatic carcinoma, epitheliallike cell line) cells were used for cell imaging.

\section{Experimental}

NMR spectra were recorded on a Bruker Ultra Shield Plus $400 \mathrm{MHz}$ NMR $\left({ }^{1} \mathrm{H}: 400 \mathrm{MHz},{ }^{13} \mathrm{C}: 100 \mathrm{MHz}\right)$. Mass spectra were obtained on a Bruker Daltonics matrix-assisted laser desorption/ionization time-of-flight mass spectrometer (MALDI-TOF-MASS). The UV-visible absorption spectra were recorded on a Shimadzu UV-3600 UV-VIS- NIR spectrophotometer. Photoluminescent spectra were measured on a RF-5301PC spectrofluorophotometer. Edinburgh instruments F900 was used to obtain the absolute quantum yield. TEM images were obtained from HT7700. BioTek PowerWave XS2 was used to study cell viability with different concentrations of the material. Confocal laser scanning microscopy (CLSM) images of the sample were recorded on Olympus, FV1000.

The 2-bromo-9,9-bis(3'-tert-butylpropanoate) fluorine (1) were synthesized according to the previous publication [18]. All chemical reagents used were purchased from Sigma-Aldrich, J\&K, and Alfa and were used as-received. Other organic solvents were used without further purification except DMF.

\subsection{Synthesis and characterizations}

Synthesis of 2-bromo-9,9-bis(3'-tert-butylpropanoate) fluorine (2). A sample $(5.01 \mathrm{~g}, 10 \mathrm{mmol})$ of $\mathbf{1},(0.35 \mathrm{~g}, 0.5$ $\mathrm{mmol})$ of $\mathrm{PdCl}_{2}\left(\mathrm{PPh}_{3}\right)_{2}$ and $(0.0952 \mathrm{~g}, 0.5 \mathrm{mmol})$ of $\mathrm{CuI}$ were dissolved in $40 \mathrm{~mL}$ of diisopropylamine. (2.156 g, 22 mmol) of trimethylsilyl acetylene was added into the vigorously stirred solution slowly at room temperature under nitrogen protection. After the addition was finished, the mixture was stirred at room temperature for $0.5 \mathrm{~h}$. The mixture was warmed to reflux temperature under constant stirring for $12 \mathrm{~h}$. After the solvent was evaporated under reduced pressure, the residue was poured into $100 \mathrm{~mL}$ of water and extracted with chloroform three times. The combined organic layer was washed with water twice and brine once and dried over $\mathrm{MgSO}_{4}$. The crude material was purified by silica gel column chromatography, using petroleum as an eluent, to give the product 1 as a slight yellow solid $(4.422 \mathrm{~g}$, 96\%): ${ }^{1} \mathrm{H}$ NMR (400 MHz, $\left.\mathrm{CDCl}_{3}\right) \delta 7.71-7.59(\mathrm{~m}, 2 \mathrm{H})$,

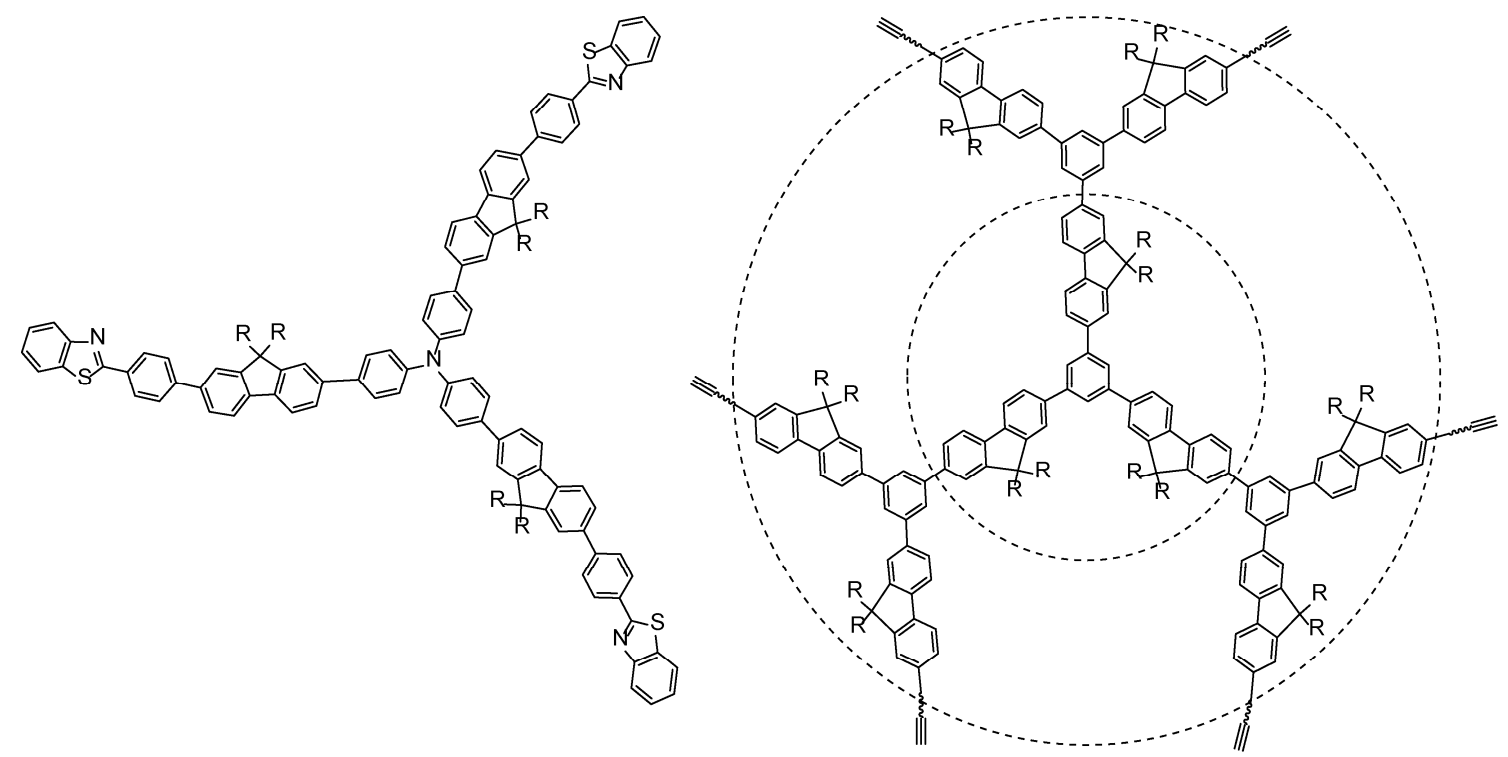

Figure 1 Chemical structures of branched polyelectrolytes (Copyright 2009 and 2011 American Chemical Society). 
$7.48(\mathrm{t}, J=3.7 \mathrm{~Hz}, 2 \mathrm{H}), 7.41-7.29(\mathrm{~m}, 3 \mathrm{H}), 2.51-2.20(\mathrm{~m}$, $4 \mathrm{H}), 1.63-1.34(\mathrm{~m}, 4 \mathrm{H}), 1.31(\mathrm{~s}, 18 \mathrm{H}), 0.28(\mathrm{~s}, 40 \mathrm{H}) \cdot{ }^{13} \mathrm{C}$ NMR $\left(\mathrm{CDCl}_{3}, \mathrm{ppm}\right): \delta 172.66,148.47,148.06,141.56$, $140.37,131.77,128.19,127.66,126.48,123.10,121.85$, 120.35, 119.82, 105.69, 94.66, 80.17, 77.34, 53.47, 34.56, 29.90, 28.00. FT-IR ( $\mathrm{KBr}$ pellet, $\mathrm{cm}^{-1}$ ): 744.52, 846.75, $1151.50,1203.58,1251.80,1286.52,1369.46,1390.68$, 1415.75, 1450.47, 1728.22, 2927.94, 2976.16, 3367.71.

Synthesis of 2-ethynyl-9,9'-bis(3'-tert-butylpropanoate) fluorine (3). In a $250 \mathrm{~mL}$ flask, $2(2.59 \mathrm{~g}, 5 \mathrm{mmol})$ was dissolved in a mixture of $\mathrm{K}_{2} \mathrm{CO}_{3}(2 \mathrm{~g}$ in $10 \mathrm{~mL}$ of water) and $50 \mathrm{~mL}$ of methanol and $50 \mathrm{~mL}$ of $\mathrm{THF}$, and stirred at room temperature for $6 \mathrm{~h}$. After evaporation of the solvent, the crude product was recrystallized with petroleum/ethyl acetate $(1: 4, \mathrm{v} / \mathrm{v})$ to afford light yellow crystals $(2.12 \mathrm{~g}$, yield 92\%). ${ }^{1} \mathrm{H}$ NMR $\left(400 \mathrm{MHz}, \mathrm{CDCl}_{3}\right): \delta 7.72-7.62(\mathrm{~m}, 1 \mathrm{H})$, $7.56(\mathrm{~d}, J=8.0 \mathrm{~Hz}, 1 \mathrm{H}), 7.53-7.46(\mathrm{~m}, 2 \mathrm{H}), 7.42-7.31(\mathrm{~m}$, $3 \mathrm{H}), 3.16(\mathrm{~s}, 1 \mathrm{H}), 2.41-2.23(\mathrm{~m}, 4 \mathrm{H}), 1.52-1.39(\mathrm{~m}, 4 \mathrm{H})$, $1.31(\mathrm{~s}, 18 \mathrm{H}) .{ }^{13} \mathrm{C} \mathrm{NMR}\left(\mathrm{CDCl}_{3}, \mathrm{ppm}\right): \delta 172.60,148.45$, $148.16,141.85,140.28,131.85,128.29,127.70,126.72$, $123.14,120.84,120.39,119.91,84.24,80.19,77.57,53.50$, 34.54, 29.93, 28.00. FT-IR ( $\mathrm{KBr}$ pellet, $\left.\mathrm{cm}^{-1}\right)$ : 746.95, $857.39,1150.441,1287.2,1370.88,1724.9,2929.74$, 2977.74, 3243.87.

Synthesis of 4,4',4"-tris(4-(9,9'-bis(3'-tert-butyl propanoate)fluorenyl-2-)ethynyl) phenylamine (TEFCOOBu) Tris(4-iodo-phenyl)-amine (311 mg, $0.5 \mathrm{mmol})$ and $2(921.2 \mathrm{mg}$, $2 \mathrm{mmol}), \mathrm{Pd}\left(\mathrm{PPh}_{3}\right)_{4}(40 \mathrm{mg}, 0.035 \mathrm{mmol}),(7.2 \mathrm{mg}, 0.035$ $\mathrm{mmol})$ of $\mathrm{CuI}, \mathrm{DMF}(5 \mathrm{~mL})$ and triethylamine (TEA) $(5 \mathrm{~mL})$ were mixed in a $25 \mathrm{~mL}$ two-neck flask. After degassing, the mixture was heated at $90^{\circ} \mathrm{C}$ with vigorous stirring for $48 \mathrm{~h}$. After the mixture was cooled to room temperature and removed the solvent, the crude material was purified by silica gel column chromatography, using petroleum/ethyl acetate $(1: 6, v / v)$ as an eluent, to give the product TEFCOOBu as a slight yellow need-like crystal $(210 \mathrm{mg}, 84 \%$ yield $) .{ }^{1} \mathrm{H}$ NMR (400 MHz, $\left.\mathrm{CDCl}_{3}\right): \delta 7.68(\mathrm{t}, J=6.8 \mathrm{~Hz}, 5 \mathrm{H}), 7.51$ $(\mathrm{dd}, J=18.3,7.6 \mathrm{~Hz}, 12 \mathrm{H}), 7.42-7.32(\mathrm{~m}, 9 \mathrm{H}), 7.13$ (d, $J$ $=8.6 \mathrm{~Hz}, 6 \mathrm{H}), 2.36(\mathrm{t}, J=8.3 \mathrm{~Hz}, 12 \mathrm{H}), 1.52-1.45(\mathrm{~m}$, $12 \mathrm{H}), 1.30(\mathrm{~s}, 54 \mathrm{H}) .{ }^{13} \mathrm{C} \mathrm{NMR}\left(\mathrm{CDCl}_{3}, \mathrm{ppm}\right): \delta 172.70$, $148.44,148.23,146.72,141.20,140.49,132.82,131.23$, $128.11,127.68,126.05,124.12,123.12,122.25,120.28$, $119.97,117.92,89.98,89.90,80.19,77.35,53.50,38.75$, 34.62, 31.60, 29.97, 28.01, 22.67, 22.63, 14.14. MS FT-IR $\left(\mathrm{KBr}\right.$ pellet, $\left.\mathrm{cm}^{-1}\right):$ 742.59, 831.32, 945.12, 1147.65, $1269.16,1284.59,1319.31,1388.75,1454.33,1506.41$, $1595.13,1728.22,2339.65,2360.87,2854.65,2926.01$, 2972.31. MALDI-TOF-MASS: $m / z$ 1578.55.

Synthesis of 4,4',4"-tris(4-(9,9'-bis(3'-tert-propanoate sodium) fluorenyl-2-)ethynyl)phenylamine (TEF-COONa) TEFCOOBu $(200 \mathrm{mg}$ ) was dissolved in dichloromethane $(20 \mathrm{~mL})$ in a $50 \mathrm{~mL}$ flask, then trifluoroacetic acid $(5 \mathrm{~mL})$ was added into the flask, and the mixture was stirred overnight at room temperature. After removal of the solvent, the yellow-green residue was treated with $\mathrm{Na}_{2} \mathrm{CO}_{3}$ aqueous solution $(0.05 \mathrm{~mol} / \mathrm{L}, 20 \mathrm{~mL})$ at room temperature for $4 \mathrm{~h}$. The polymer was purified through dialysis against distilled water for $3 \mathrm{~d}$. The solution was freeze-dried to give TEFCOONa (65 mg, 76\% yield) as yellow powder. ${ }^{1} \mathrm{H}$ NMR (400 MHz, $\left.\mathrm{CD}_{3} \mathrm{OD}\right): \delta 7.81(\mathrm{~d}, 4 \mathrm{H}), 7.67(\mathrm{~s}, 5 \mathrm{H}), 7.52(\mathrm{~s}$, 2H), 7.43-7.35 (m, 9H), 7.27 (s, 5H), 6.99 (dd, $J=15.6,8.0$ $\mathrm{Hz}, 8 \mathrm{H}), 2.32(\mathrm{~m}, 12 \mathrm{H}), 1.36(\mathrm{~m}, 12 \mathrm{H})$. FT-IR (KBr pellet, $\mathrm{cm}^{-1}$ ): 3410.15(br), 2956.87, 2920.23, 1276.87, 2852.72, $1658.78,1658.78,1591.27,1568.13,1548.84,1506.41$, $1446.61,1386.82,1317.38,1172.72,835.18,740.67$.

\subsection{Results and discussions}

The synthetic route of the oligomers is shown in Figure 2. Compound 1 was prepared in $71 \%$ yield by direct alkylation of 2-dibromofluorene with tertbutyl acrylate in a toluene/ aqueous $\mathrm{KOH}$ mixture, which was followed by purification using silica column chromatography. $\mathbf{2}$ was synthesized under Sonogashira reaction conditions in the presence of $\mathrm{PdCl}_{2}\left(\mathrm{PPh}_{3}\right)_{2}$, CuI, (trimethylsilyl)acetylene using dry diisopropylamine as the solvent. The NMR spectroscopy, MS, FT-IR spectroscopy results show that the products were obtained in the correct structures with high purity. Oligomerization between TIPA and $\mathbf{3}$ was conducted in a mixture solution of DMF and TEA under nitrogen atmosphere for $24 \mathrm{~h}$ to yield TEFCOOBu. The ${ }^{1} \mathrm{H}$ NMR spectrum of TEFCOOBu in $\mathrm{CDCl}_{3}$ has shown a chemical shift of 1.30 ppm, which corresponds to the protons for the $-\mathrm{C}\left(\mathrm{CH}_{3}\right)_{3}$ group, indicating the existence of carboxylic ester groups. TEFCOOBu is soluble in organic solvents. TEFCOONa was produced by hydrolysis of TEFCOOBu in the presence of $\mathrm{CF}_{3} \mathrm{COOH}$ and dichloromethane, which was followed by reaction with $0.1 \mathrm{~mol} / \mathrm{L} \mathrm{Na}_{2} \mathrm{CO}_{3}$ overnight at room temperature. It was obtained in $76 \%$ yield after purification through dialysis (cutoff molecular weight 500) against DI water for $3 \mathrm{~d}$ to remove salt and small molecular weight fractions. According to the ${ }^{1} \mathrm{H}$ NMR spectrum of TEFCOONa, the chemical shift at $1.30 \mathrm{ppm}$ disappeared, which indicated the complete conversion of $-\mathrm{COOC}\left(\mathrm{CH}_{3}\right)_{3}$ to -COONa. Different from TEFCOOBu, TEFCOONa is soluble in water and methanol.

\section{Optical properties and self-assemble behaviors}

The UV-Vis and PL spectra of TEF-COONa in water are shown in Figure 3. The oligomer has an absorption maximum of 330 and $376 \mathrm{~nm}$ and emits green-blue fluorescence with a main peak at $446 \mathrm{~nm}$. These good optical properties are directly related to its geometrical structure, where the triphenylamine are chosen as the core because of its electron-rich and unique "propeller" type of structure, modified fluorenes are chosen as branches to extend the con-jugation length through the 3-D structure. All of these groups were 


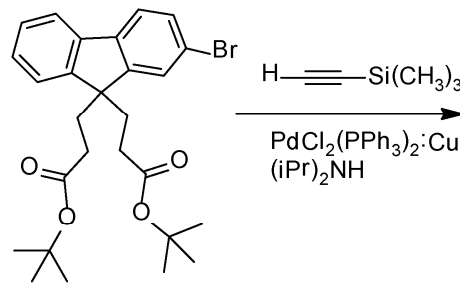

1

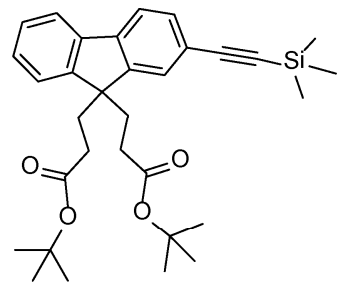

2

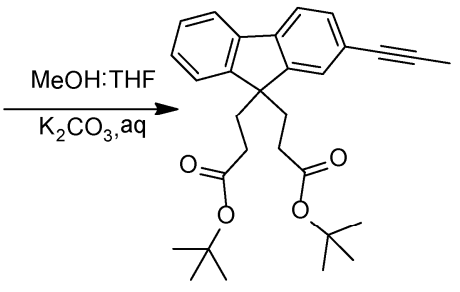

3

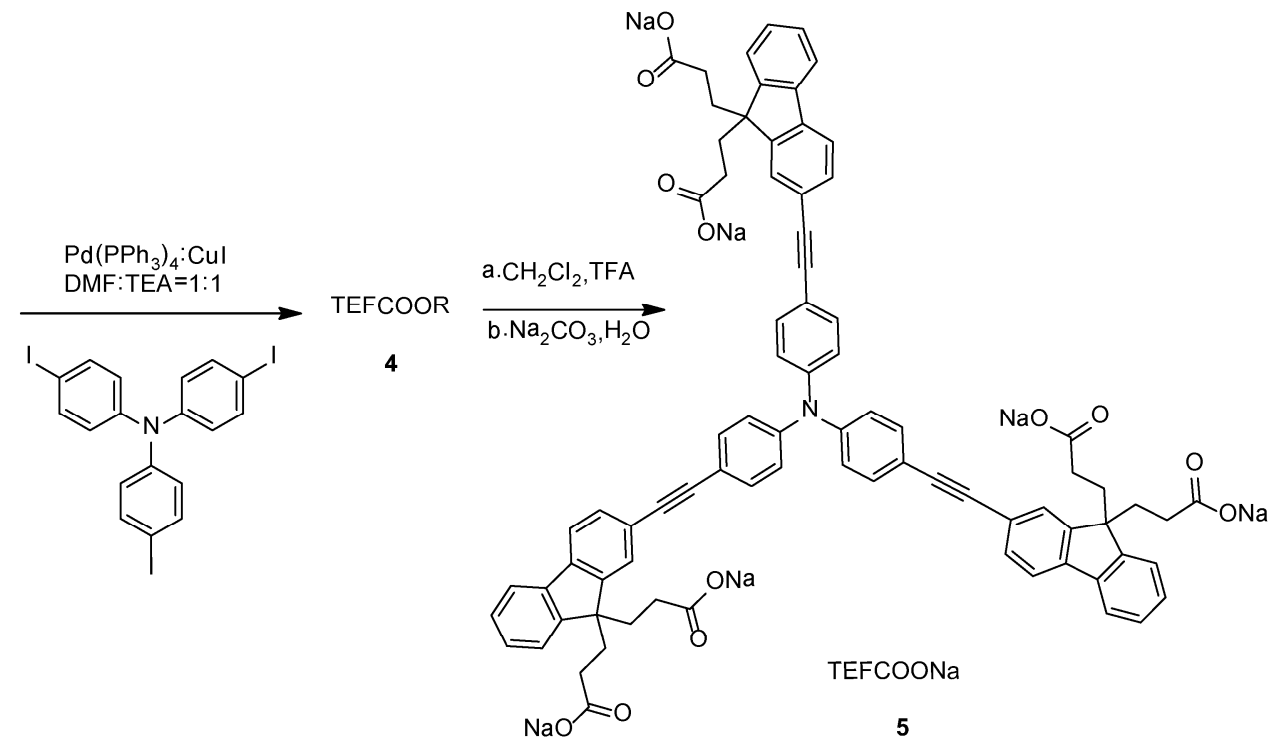

Figure 2 Synthetic route for oligomers $\mathbf{4}$ and $\mathbf{5}$.

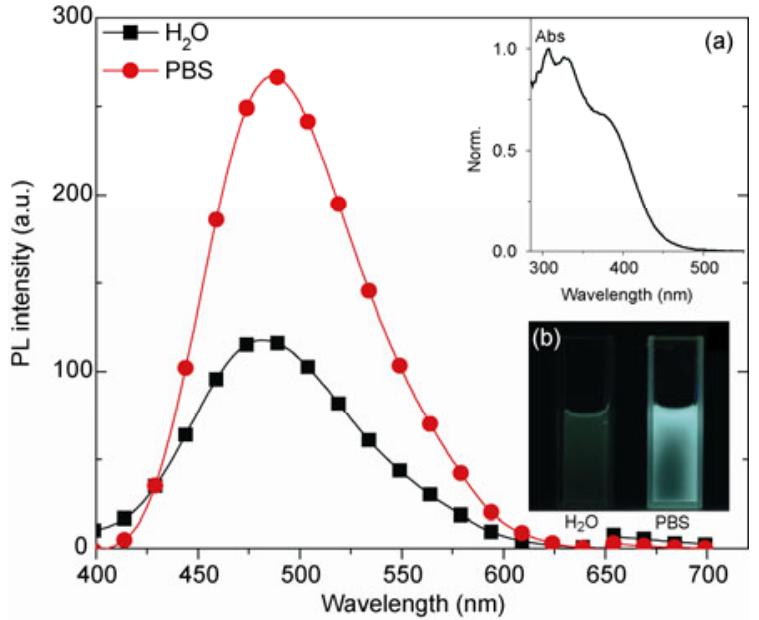

Figure 3 PL spectra $\left(\lambda_{\mathrm{ex}}=330 \mathrm{~nm}\right)$ of TEFCOONa $(50 \mu \mathrm{g} / \mathrm{mL})$ in water (black) and in $10 \mathrm{mmol} / \mathrm{L}$ PBS (red). (a) UV-Vis absorption spectrum of TEFCOONa in water; (b) the emission photos $\left(\lambda_{\mathrm{ex}}=365 \mathrm{~nm}\right)$ observed of TEFCOONa in water and $10 \mathrm{mmol} / \mathrm{L} \mathrm{PBS}$.

linked by acetylene leading to effective $\pi$-electron delocalization and high fluorescence quantum yield in water. Furthermore, the unique star-shaped structure can avoid $\pi-\pi$ stacking to some extent, which is of benefit for the properties.

The effect of the buffer solution on the optical properties of the oligomer was investigated. The PL spectra of 50 $\mu \mathrm{g} / \mathrm{mL}$ TEFCOONa in $10 \mathrm{mmol}$ PBS buffer $(10 \mathrm{mmol} / \mathrm{L}$, $\mathrm{pH} \sim 7.4$ ) are shown in Figure 3. The maximum emission wavelength red shifts (about $7 \mathrm{~nm}$ ) in buffer solution is compared with that in water. And fluorescence intensity increases notably in buffer solution. The PL quantum yields of TEFCOONa in water and PBS buffer solution are $6.3 \%$ and $16.5 \%$, respectively. Figure 3(b) shows the differences clearly. These features are good for avoiding cellular autofluorescence [11], when the materials were used for cellular imaging in PBS buffer solution.

Dynamic light scattering (DLS) was performed to probe the self-assemble behaviors of TEFCOONa in buffer solution. Figure 4(a) shows the results of DLS in water. The mean hydrodynamic diameter was measured to be $\sim 85 \mathrm{~nm}$, with a polydispersity of 0.287 . Hydrophobic conjugated frameworks and low space charge density of the ligoelectrolyte may be the reasons of self-assemble. The morphology of the oligoelectrolyte in dry state is studied by TEM. The sample was prepared by drop-coating the polymer aqueous solution $(50 \mu \mathrm{g} / \mathrm{mL})$ onto Copper Grid Lacey Carbon Film, followed by evaporation in the air. As shown in Figure 4(b), the oligoelectrolyte forms nearly uniform nanospheres $(\sim 75 \mathrm{~nm})$. The size measured from TEM is slightly smaller than that obtained from DLS, which should be caused by the shrinkage of the flexible chains of TEFCOONa during the drying process. In addition, these dark 


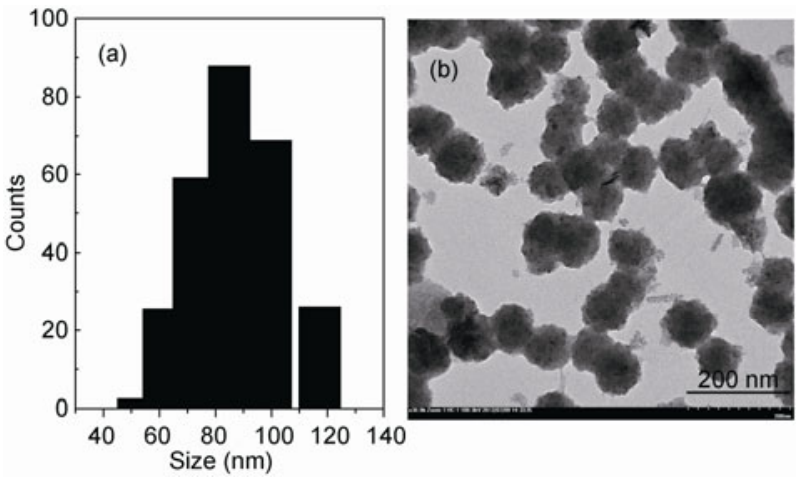

Figure 4 DLS (a) and TEM (b) images of TEFCOONa nanospheres in 10 $\mathrm{mmol} / \mathrm{L}$ PBS with a scale bar of $200 \mathrm{~nm}$.

cores of nanospheres correspond to the areas enriched with the conjugated segments. And the bright fluorescence from these aggregated conjugated segments can satisfy the requests for cell imaging absolutely.

\section{Cell viability assays and bioimaging}

Cellular viability was determined by the MTT assay which is based on the ability of the mitochondrial succinatetetrazolium reductase system to convert 3-(4,5-dimethylthiazol-2-yl)-2,5-diphenyltetrazolium bromide (MTT, Sigma) to a purple-colored formazan in living cells. RAW 264.7 cells were incubated on 96 multi-well plates with 0.1 mL RPMI-1640 medium containing $10 \%$ calf serum and $1 \%$ penicillin/streptomycin and $0.5 \times 10^{4}$ cells per well at $37^{\circ} \mathrm{C}$ $\left(5 \% \mathrm{CO}_{2}, 95 \%\right.$ air) for $48 \mathrm{~h}$. Next, the medium without serum supplemented with indicated doses of conjugated polymers was used to incubate the cells for $24 \mathrm{~h}$. Then $0.01 \mathrm{~mL}$ of $0.5 \%$ MTT solution was added to every well at $37^{\circ} \mathrm{C}$. Four hours later, the supernatant was removed, and the product was lysed with $0.15 \mathrm{~mL}$ thylsulfoxide. Formazan absorbance was recorded at $490 \mathrm{~nm}$ using BioTek PowerWave XS2. The mean absorbance of non-exposed cells was the reference value for calculating $100 \%$ cellular viability.

\subsection{Cell viability assays}

Cellular morphology treated with different concentrations of TEFCOONa $0.1 \mu \mathrm{g} / \mathrm{mL}$ and $1 \mu \mathrm{g} / \mathrm{mL}$ is displayed in Figure 6(a) and (b), respectively. Figure 6(c) shows the viability of RAW 264.7 cells after being cultured with TEFCOONa in PBS solution at the concentrations of $0.1 \mu \mathrm{g} / \mathrm{mL}$ and 1 $\mu \mathrm{g} / \mathrm{mL}$ for $24 \mathrm{~h}$. The cell viabilities are close to $100 \%$ within the tested period of time, which indicates low cytotoxicity of materials. All of these prove the low cytotoxicity of TEFCOONa, which would be of benefit for cellular imaging in vitro or in vivo and other clinical applications.

\subsection{One-photon fluorescence imaging}

PANC-1 cells were incubated on 24 multi-well plates with $0.1 \mathrm{~mL}$ RPMI-1640 medium containing $10 \%$ calf serum and $1 \%$ penicillin/streptomycin and $0.5 \times 10^{4}$ cells per well at $37^{\circ} \mathrm{C}\left(5 \% \mathrm{CO}_{2}, 95 \%\right.$ air $)$ for $24 \mathrm{~h}$. Next, the DMEM medium
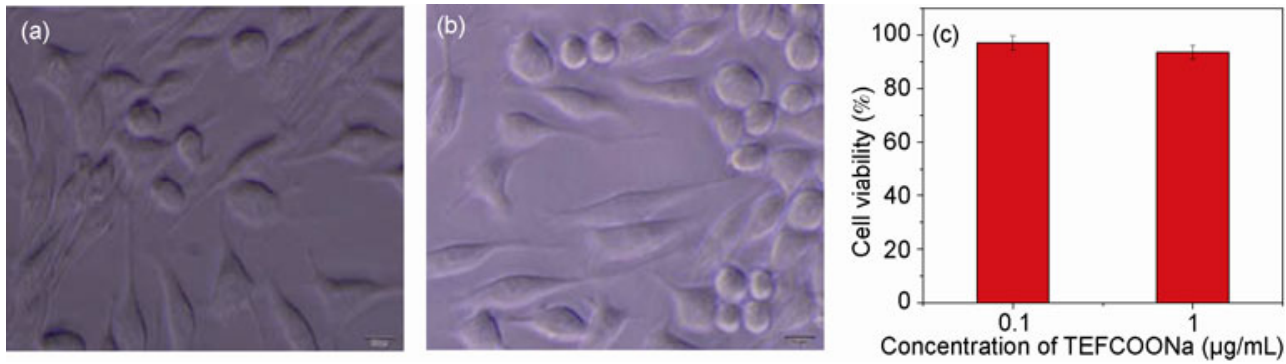

Figure 5 Characterization of living RAW 264.7 cells treated with the TEFCOONa nanospheres solution $(0.1 \mu \mathrm{g} / \mathrm{mL})(\mathrm{a}),(1 \mu \mathrm{g} / \mathrm{mL})$ (b) for $24 \mathrm{~h}$ and the corresponding cell viability (c) of living RAW 264.7 cells.
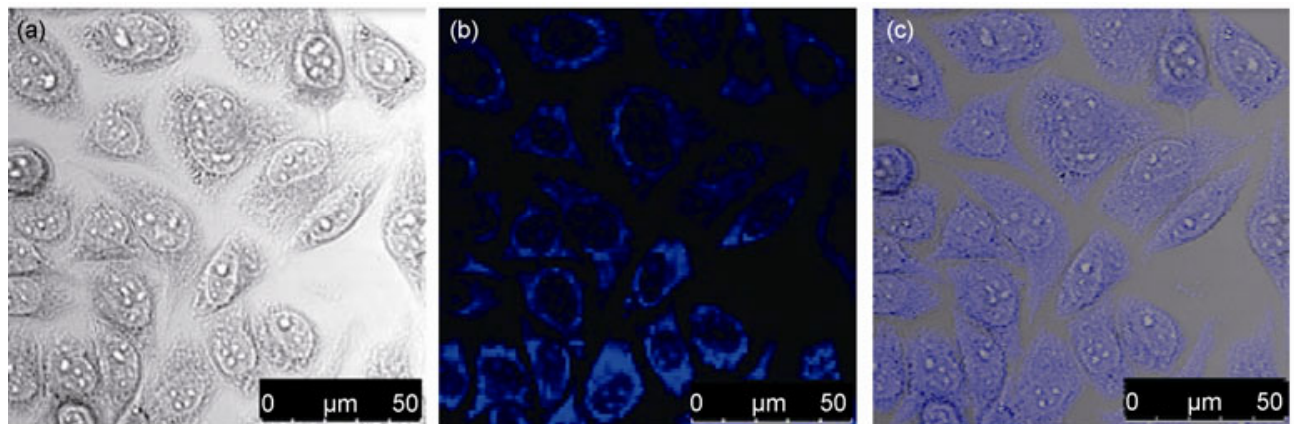

Figure 6 Fluorescence confocal microscopy images (CLSM) images of TEFCOONa (50 $\mu \mathrm{g} / \mathrm{mL}$ ) aggregates in PBS solution. (a) Bright field; (b) excited wavelength at $405 \mathrm{~nm}$; (c) merging of (a) and (b). 
without serum supplemented with $0.005 \mathrm{mg} / \mathrm{mL}$ conjugated polymers was used to incubate the cells at the same incubated condition. After incubation for $2 \mathrm{~h}$, cells were washed three times with PBS buffer and then fixed by $75 \%$ ethanol for $20 \mathrm{~min}$ and further washed twice with PBS buffer solution and imaged by CLSM, Olympus, FV1000, Japan, with imaging software Fluoview FV1000.

The relatively strong PL intensity of TEFCOONa ranging from 400 to $500 \mathrm{~nm}$ allows collecting strong fluorescent signal. The confocal laser scanning microscopy (CLSM) images of the sample are displayed in Figure 6. Figure 6(b) is the fluorescence image and Figure 6(c) is overlapped image of Figure 6(a) and (b). It is noteworthy that the fluorescence of TEFCOONa nanospheres in cells is strong. This is ascribed to the unique structure of the oligoelectrolyte. Meanwhile, according to the CLSM images, it is noteworthy that the fluorescence from the cells treated with TEFCOONa nanospheres is strong. And the fluorescence from the nucleolus of is visible. These implicate that these nanospheres are efficiently internalized by the cells and accumulated in the cytoplasm even in the nucleolus. The results provide a facile strategy to prepare a new series of hypebranched polymers with tagging capability and controllable properties for biological applications.

\section{Conclusions}

In conclusion, we take advantage of Sonogashira reaction to construct a new water-soluble oligoelectrolyte 4,4',4"-tris (4-(9,9'-bis(3'-tert-propanoatesodium)fluorenyl-2-)ethynyl) phenylamine (TEF-COONa). The oligoelectrolyte has an effective conjugated core and anionic arms, which intrinsically forms nanospheres with an average diameter of $\sim 75$ $\mathrm{nm}$ according to TEM images. The inherent water miscibility and star-shaped architecture endow these nanospheres with relatively high absolute PL quantum yield in buffer solution (16.5\%), allowing cell imaging in an efficient and bright fashion. As a result, this investigation provided a new candidate for biological imaging. Besides, compounds with quadrupolar (D- $\pi$-D), and three-branched architecture have the potential to be materials of Two-Photon Absorption (TPA) according to the previous reports [19-21], which is good for two-photon fluorescence imaging.

This work was supported by the National Basic Research Program of China (2009CB930600, 2012CB933301 and 2012CB723402), the Ministry of Education of China (IRT1148), the National Natural Science Foundation of China (21222404, 51173080 and 21104033), the Program for New Century Excellent Talents in University (NCET-10-0179), the Specialized Research Fund for the Doctoral Program of Higher Education (20093223110003), the Natural Science Foundation of Jiangsu Province of China (BZ2010043 and NY211003), and the Program for Postgraduates
Research Innovation of Colleges and Universities of Jiangsu Province (CXLX11_0424 and CXLX11_0424_0414)

1 Xia F, Heeger A J, Plaxco K W, et al. On the binding of cationic, water-soluble conjugated polymers to DNA: Electrostatic and hydrophobic interactions. J Am Chem Soc, 2010, 132: 1252-1254

2 Satrijo A, Swager T M. Anthryl-doped conjugated polyelectrolytes as aggregation-based sensors for nonquenching multicationic. J Am Chem Soc, 2007, 129: 16020-16028

3 McQuade D T, Hegedus A H, Swager T M. Signal amplification of a "turn-on" sensor: Harvesting the light captured by a conjugated polymer. J Am Chem Soc, 2000, 122: 12389-12390

4 Ho H A, Leclerc M. Optical sensors based on hybrid aptamer/conjugated polymer complexes. J Am Chem Soc, 2004, 126: 1384-1387

5 Ho H A, Leclerc M. New colorimetric and fluorometric chemosensor based on a cationic polythiophene derivative for iodide-specific detection. J Am Chem Soc, 2003, 125: 4412-4413

6 Dore K, Boudreau D, Leclerc M. Fluorescent polymeric transducer for the rapid, simple, and specific detection of nucleic acids at the zeptomole level. J Am Chem Soc, 2004, 126: 4240-4244

7 Zhang Z Y, Fan Q L, Huang W, et al. Highly selective anionic counterion-based fluorescent sensor for $\mathrm{Hg}^{2+}$ by grafted conjugated polyelectrolytes. Macromol Rapid Commun, 2010, 31: 2160-2165

8 Xue W X, Zhang D Q, Zhu D B, et al. Colorimetric detection of glucose and an assay for acetylcholinesterase with amine-terminated polydiacetylene vesicles. Chin Sci Bull, 2011, 56: 1877-1883

9 Fan Q L, Huang W, Zhou Y, et al. Water-soluble cationic poly(pphenyleneethynylene)s (PPEs): Effects of acidity and ionic strength on optical behavior. Macromolecules, 2005, 38: 2927-2936

$10 \mathrm{Kim}$ I K, Shin H, Bunz U H F, et al. Use of a folate-PPE conjugate to image cancer cells in vitro. Bio Chem, 2007, 18: 815-820

$11 \mathrm{Pu} \mathrm{K} \mathrm{Y,} \mathrm{Li} \mathrm{K,} \mathrm{Liu} \mathrm{B,} \mathrm{et} \mathrm{al.} \mathrm{Fluorescent} \mathrm{single-molecular} \mathrm{core-shell}$ nanospheres of hyperbranched conjugated polyelectrolyte for livecell imaging. Chem Mater, 2009, 21: 3816-3822

12 Wang G, Lai Y H, Liu B, et al. Star-shaped glycosylated conjugated oligomer for two-photon fluorescence imaging of live cells. Chem Mater, 2011, 23: 4428-4434

13 Schacher F, Walther A, Muller A H E, et al. Multicompartment core micelles of triblock terpolymers in organic media. Macromolecules, 2009, 42: 3540-3548

14 Lai W Y, Huang W, Zhou R, et al. Monodisperse six-armed triazatruxenes: Microwave-enhanced synthesis and highly efficient pure-deepblue electroluminescence. Macromolecules, 2006, 39: 3707-3709

15 Lai W Y, Huang W, He Q Y, et al. Kinked Star-shaped fluorene/triazatruxene co-oligomer hybrids with enhanced functional froperties for high-performance, solution-processed, blue organic light-emitting diodes. Adv Funct Mater, 2008, 18: 265-276

16 Lo S C, Burn P L. Development of hyperbranched polymers polymers: Macromolecules for use in organic light-emitting diodes and solar cells. Chem Rev, 2007, 107: 1097-1166

17 Li K, Pu K Y, Liu B. Phalloidin-functionalized hyperbranched conjugated polyelectrolyte for filamentous actin imaging in living Hela cells. Chem Mater, 2011, 23: 2113-2119

18 Gaylord B S, Heeger A J, Bazan G C. DNA detection using watersoluble conjugated polymers and peptide nucleic acid probes. Proc Natl Acad Sci USA, 2002, 99: 10954-10957

19 Pawlicki M, Collins H A, Anderson H L, et al. Two-photon absorption and the design of two-photon dyes. Angew Chem Int Ed, 2009, 48: 3244-3266

20 Terenziani F, Katan C, Badaeva E, et al. Enhanced two-photon absorption of organic chromophores: Theoretical and experimental assessments. Adv Mater, 2008, 20: 4641-4678

21 He G S, Tan L S, Zheng Q, et al. Multiphoton absorbing materials: Molecular designs, characterizations, and applications. Chem Rev, 2008, 108: 1245-1330

Open Access This article is distributed under the terms of the Creative Commons Attribution License which permits any use, distribution, and reproduction in any medium, provided the original author(s) and source are credited. 